\title{
Perancangan Absensi Berbasis Face Recognition Pada Desa Sokaraja Lor Menggunakan Platform Android
}

\author{
Darmansah* $^{*}$, Ni Wayan Wardani ${ }^{2}$, M. Yoka Fathoni ${ }^{3}$ \\ ${ }^{1,3}$ Institut Teknologi Telkom Purwokerto; Jl. DI. Panjaitan No.128 Purwokerto, \\ Telp 0281-641629 \\ ${ }^{2}$ STMIK STIKOM Indonesia; Jl. Tukad Pakerisan No. 97 Panjer, Denpasar \\ e-mail: *11armansah@ittelkom-pwt.ac.id, ${ }^{2}$ niwayan.wardani@stiki-indonesia.ac.id, \\ ${ }^{3}$ myokafathoni@ittelkom-pwt.ac.id
}

\begin{abstract}
Abstrak
Perkembangan teknologi saaat ini sangat cepat diberbagai bidang kehidupan manusia. Salah satu penggunaan teknologi adalah di bidang absensi. Absensi merupakan bagian terpenting dalam sebuah instansi, baik instansi pendidikan, kesehatan, perkantoran dan pemerintahan dalam menunjang memonitor kehadiran sehari hari karyawan. Desa Sokaraja Lor merupakan sebuah desa yang terletak di Kecematan Sokaraja Kab. Banyumas Jawa Tengah. Saat ini proses absensi di kantor desa Sokaraja Lor tersebut masih menggunakan Pinjer Print dan juga menggunakan pencatatan menggunakan buku besar. Penggunaan pinjer print ini dinilai kurang efektif karena apa bila tanggan pegawai desa tersebut basah, atau luka maka absensi tidak dapat dilakukan dan ini juga berisiko pegawai desa bisa titip absen kepada pegawai lainnya. Melihat hal itu peneliti merancang sebuah sistem absensi berbasis Face Recognition dengan menggunakan Platform Android. Absensi berbasis Face recognition merupakan absensi yang dilakukan menggunakan deteksi bagian wajah manusia. Kemudian didalam perancangan sistem absensi berbasis face recognition ini peneliti menggunakan pemodelan sistem dengan Undifinied Modeling Language (UML). Dengan dibangunnya sistem absensi ini Desa Sokaraja Lor dapat lebih mudah dalam melakukan absensi dalam setiap kondisi karena sudah berbasis android, kemudian dalam merekap daftar pegawai yang hadir pemarintah desa lebih gampang karena sudah tersimpan dalam sebuah database.
\end{abstract}

Kata kunci-Perancangan, Absensi, Face Recognition, UML, Android

\begin{abstract}
The development of technology is currently very fast in various fields of human life. One of the uses of technology is in the field of attendance. Attendance is the most important part in an institution, both education, health, offices and government agencies in supporting monitoring of employees' daily attendance.Sokaraja Lor Village is a village located in Sokaraja District, Kab. Banyumas, Central Java.Currently the attendance process at the Sokaraja Lor village office is still using Pinjer Print and also using notes using a ledger.The use of this print pin is considered ineffective because if the village employee's hands are wet, or injured, attendance cannot be done and this is also a risk that village employees can leave absences to other employees.Seeing this, the researchers designed an attendance system based on Face Recognition using the Android platform. Face recognition-based attendance is attendance
\end{abstract}


which is done using the detection of human face parts.Then in designing the face recognitionbased attendance system, the researchers used a system modeling with Undifinied Modeling Language (UML). With the construction of this attendance system, Sokaraja Lor Village can make attendance easier in every condition because it is based on Android, then in recapitulating the list of employees who are present, the village government is easier because it has been stored in a database.

Keywords-Perancangan, Absensi, Face Recognition, UML, Android

\section{PENDAHULUAN}

$P^{s}$ manfaatan teknologi informasi dalam era sakarang ini sangatlah begitu penting. Hal ini seiring dengan perkembangan teknologi informasi yang semakin cepat dan semakin canggih. Teknologi saat ini di gunakan diberbagai aspek kehidupan manusia saaat ini telah menggunakan teknologi informasi didalam kehidupan sehari hari, baik di dalam dunia bisnis maupun dalam dunia pendidikan, kesehatan, pemerintahan dan lain sebagainya [1]. Hal ini juga tidak terlepas dalam penerapan teknologi dalam absensi karyawan, baik karyawan swasta maupun negeri. Absensi merupakan sebuah kegiatan yang sering dilakukan hampir setiap hari baik untuk pegawai di tempat pekerjaan, saat ini perangkat absensi yang digunakan pegawai atau masyarakat cukup berkembang dan beragam seperti salah satunya telah menggunakan sidik jari dan lain-lain sebagainya, tetapi sangat di sayangkan sekali metode absensi tersebut masih memiliki beberapa kekurangan seperti kerusakan perangkat keras, kemudian kehilangan perangkat keras, dan biaya untuk perbaikan/perawatan lumayan besar[2]. Absensi kehadiran pegawai merupakan sebuah faktor yang penting bagi sebuah kantor pemerintahan atau sebuah perusahaan untuk mencapai tujuan pekerjaan, hal ini berkaitan pada kedisiplinan yang berdampak pada kinerja dari masing-masing pegawai tersebut [3]. Desa Sokaraja Lor adalah satu satu instansi pemerintahan yang berada di Kabupaten Banyumas. Kantor Desa Sokaraja Lor merupakan sebuah instansi pemerintahan yang menjalankan tugas sehari hari dalam melayani penduduk desa setempat dari mulai surat menyurat dari pagi hari sampai sore hari. Tetapi saat ini kantor desa Sokaraja Lor didalam memonitor kehadiran pegawai desa atau staf desa belum memaksimalkan teknologi informasi. Hal ini terlihat dari absensi yang dilakukan masih menggunakan sebuah mesin pinjer print dan buku besar. Penggunaan pinjer print ini dinilai kurang efektif karena dalam prakteknya sehari hari banyak kendala yang ditemui pegawai desa tersebut, salah satunya adalah kesusahan saat melakukan absensi dikarenakan jari yang basah atau tangan yang luka. Kemudian jika hal tersebut tejadi pegawai terpaksa menggunakan buku besar dalam pencatatan kehadirannya. Hal ini tentu timbul sebuah kecurang dalam melakukan absensi karena bisa saja pegawai melakukan titip absen kepada pegawai lainnya, kemudian didalam perekapan data absensi juga sulit. Melihat permasalahan tersebut peneliti merancang sebuah sistem yang bisa menjawab permasalahan absensi di kantor desa tersebut. Peneliti merancang sebuah sistem absensi yang berbasis face recognition menggunakan platform android. Kemudian dalam pemodelan peracangan sistem peneliti menggunakan pemodelan Undifinied Modeling Language (UML). UML merupakan sebuah bahasa yang digunakan sebagai visuualisasi, spesifikasi, merancang sebuah system perangkat lunak dan dokumentasi [4]. UML juga dipakai di dunia industry yang digunakan untuk mengambarkan, membuat dan mendesain arsitektur sebuah pemprograman berorientasi pada objek [5] . Dengan dirancangannya sistem absensi ini pegawai desa tersebut lebih tertib dan mudah dalam melakukan absensi kemudian juga mudah dalam mengelola data absensi pegawai. Face recognition sendiri adalah sebuah skema atau cara absensi yang lakukan menggunakan

Darmansah, et.,al (Perancangan Absensi Berbasis Face Recognition Pada Desa Sokaraja Lor Menggunakan Platform Android) 
pengenalan wajah atau pencocokan wajah yang sudah direkam sebelumnya kedalam sebuah sistem. face recognition mencocokkan gambar wajah masukan dengan gambar yang ada padas uatu data base wajah dan mencari wajah yang sesuai dengan gambar masukan [6]. face recognition merupakan pencarian dan pengindeksan kedalam database dengan cara mengenali identitas diri seseorang secara otomatis dengan menggunakan teknologi computer [7]. Face Recognition ialah sebuah sistem yang digunakan untuk mencatat kehadiran sebuah pegawai perusahaan atau instansi dengan memakai sebuah metode pendeteksi wajah manusia [8]. Sedangkan Android merupakan sebuah system operasi perangkat mobile berbasis Linux yang mencakup system operasi, middleware dan aplikasi. Android juga merupakan platform terbuka bagi para pengembang untuk membuat aplikasi [9]. Pengunaan android pada penenlitian ini didasari kepada fakta bahwa saat ini pertumbuhan pengguna menggunakan android yang berkembang pesat dan mudah di gunakan [10]. Android juga sebuah sistem operasi berbasis Linux yang dirubah untuk perangkat bergerak yang terdiri dari system operasi, middleware dan aplikasi aplikasi utama [11]. Android juga merupakan sebuah system operasi yang di rancang oleh google dengan basis kernel linux untuk membantu kerja sebuah perangkat elektronik layar sentuk seperti smartphone dan sejenisnya [12]. [13], [14], [15].

\section{METODE PENELITIAN}

Pada penelitian ini peneliti menggunakan beberapa metode diantaranya yaitu pengumpul data primer, sekunder, analisis masalah dan analisis sistem.

\subsection{Pengumpulan Data Primer}

Pada penelitian ini data dikumpulkan sendiri oleh peneliti dari sumber pertama atau dimana tempat penelitian dilakukan. Peneliti mendapatkan data primer dari 2 sumber yaitu Observasi dan wawancara. Observasi ialah metode untuk pengumpulan data lapangan yang dilakukan melalui pengamatan secara langsung ke bagian administrasi yang dituju untuk melihat proses pencatatan absensi pegawai yang sedang berjalan pada Desa Sokaraja Lor. Data yang diperoleh dari metode observasi meliputi proses pencatatan absensi secara manual. Sedangkan Wawancara adalah metode pengumpulan data yang dilakukan dengan mengajukan beberapa pertanyaan pada narasumber dalam kerja praktik ini adalah pegawai Desa Sokaraja Lor mengenai kendala yang dihadapi dalam proses absensi pada. Data yang diperoleh dari wawancara tersebut meliputi bagaimana proses pencatatan absensi yang sedang berlangsung serta permasalahan yang sedang dihadapi dalam proses absensi tersebut.

\subsection{Pengumpulan Data sekunder}

Data sekunder merupakan pengumpulan data secara tidak langsung, dimana dalam pengumpulan data sekunder diperoleh dalam bentuk dokumen, buku-buku dan media lainnya. Peneliti mendapatkan data sekunder dari 2 cara yaitu dokumentasi dan perpustakaan. Dokumentasi data seperti data proses absensi serta permasalahan dalam proses absensi tersebut. Sedangkan dilakukannya studi pustaka untuk memperoleh teori yang memperdalam pengetahuan dalam perancangan sistem absensi berbasis Face Recognition. Data yang didapat berasal dari jurnal ilmiah, buku-buku maupun media lainnya, kemudian hasil penelitian dan sejenisnya yang mendukung teori dasar perancangan sistem absensi berbasis facerecognition Desa Sokaraja Lor.

\subsection{Analisis Masalah}

Adapun analisis masalah pada penelitian ini sebagai berikut: 
1. Pada sistem yang lama proses absensi dilakukan dengan cara pegawai datang dan mengisi absensi di buku besar yang sudah disediakan pada meja kehadiran, Hal ini menimbulkan celah kelemahan yaitu kemungkinan terjadinya kecurangan dalam pencatatan kehadiran. Kecurangan ini sering disebut titip absen.

2. Pada sistem yang lama pihak instansi mengalami kesusahan dalam merekap daftar hadir atau absensi pegawai karena buku untuk pencatatan absensi karyawan sering hilang, kemudian jika penggunaan pinjer print juga kurang mendukung. Dengan ini di bangun sebuah sistem yang berbasis android yang memudahkan Desa Sokaraja Lor untuk mengelola data absensi pegawai.

\subsection{Analisis Sistem}

Sistem yang akan dirancangan dalam proses absensi berbasis facerecognition atau pencocokan wajah pada Desa Sokaraja Lor ini merupakan sistem tentang user (pengguna sistem) dalam hal ini ada 2 user yang dapat mengakses sistem yaitu seluruh Staf atau pegawai dan Admin, Sistem yang dibangun meliputi pendeteksian wajah dari kamera smartphone pegawai, proses pencocokan wajah di smartphone pegawai, hingga pengiriman status verifikasi kehadiran ke database server. Dalam perancangan sistem absensi berbasis pencocokan wajah atau facerecognition terdapat 3 tahapan yaitu:

1. Tahap input

Pada tahap ini input aplikasi yang diberikan adalah pemilihan fitur verifikasi kehadiran dengan pencocokan wajah oleh pegawai desa, kemudian fitur kelola data wajah pegawai dan pemilihan fitur verifikasi kehadiran.

2. Tahap proses

Pada tahap ini, aplikasi mobile sistem absensi ini melakukan proses pendaftaran data wajah dari client ke sistem server, proses unggah dan unduh data wajah dari dan ke database server dengan penyimpanan internal smartphone, proses training data set wajah, proses face detection dan facerecognition, serta proses pengiriman status verifikasi kehadiran pegawai.

3. Tahap Output

Output dari aplikasi mobile sistem kehadiran pegawai ini adalah pengiriman status pegawai berhasil melakukan verifikasi kehadiran ke sistem server dan juga laporan hasil dari presensi tersebut.

\section{HASIL DAN PEMBAHASAN}

Bagian ini peneliti menyajikan beberapa pembahasan atau rancangan sistem absensi Desa Soakaraja Lor menggunakan pemodel UML.

\subsection{Perancangan Sistem}

Bagian ini memuat data-data hasil penelitian yang dapat disajikan dalam bentuk deskripsi, tabel, grafik, maupun gambar. Perancangan sistem ini memberikan gambaran yang jelas dan menghasilkan rancangan bangun yang terlibat dalam perancangan atau pembangunan sistem, maka dalam penelitian ini menggunakan perancangan sitem Unified Modelling Language (UML) dimana melibatkan beberapa alur-alur perancangan sistem diantaranya:

1. Use Case Diagram

2. Activity Diagram

3. Sequence Diagram

4. Class Diagram 


\subsection{Use Case Diagram}

Use case diagram merupakan diagram yang menggambarkan interaksi antara sistem dengan sistem eksternal dan pelaku-pelakunya pada gambar 1 dibawah ini:

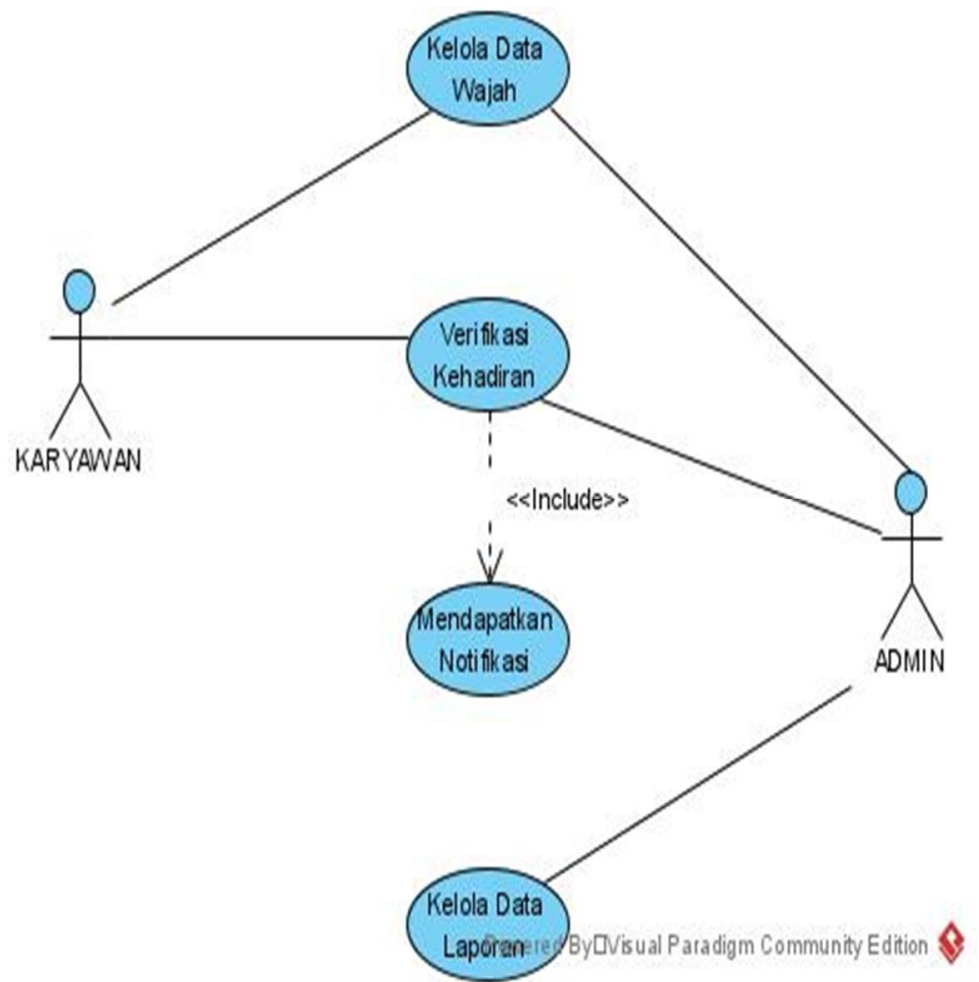

Gambar 1. Use Case Diagram

\subsection{Activity Diagram}

Activity Diargam ialah sebuah teknik untuk menggambarakn logika prosedural, proses bisnis dan jalur kerja. Terdapat 3 user yang memiliki hak untuk mengelola sistem, Yaitu sebagai gambar 2,3 dan 4 berikut ini: 


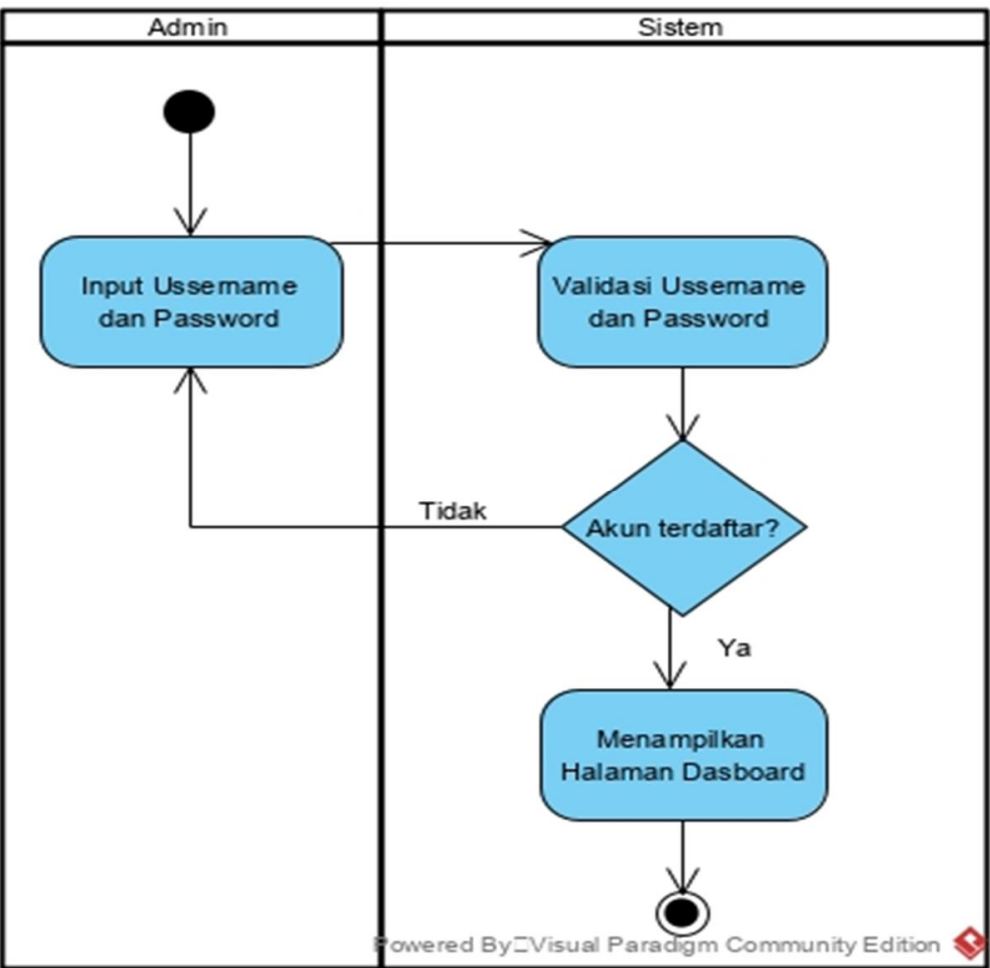

Gambar 2. Activity Diagram Login

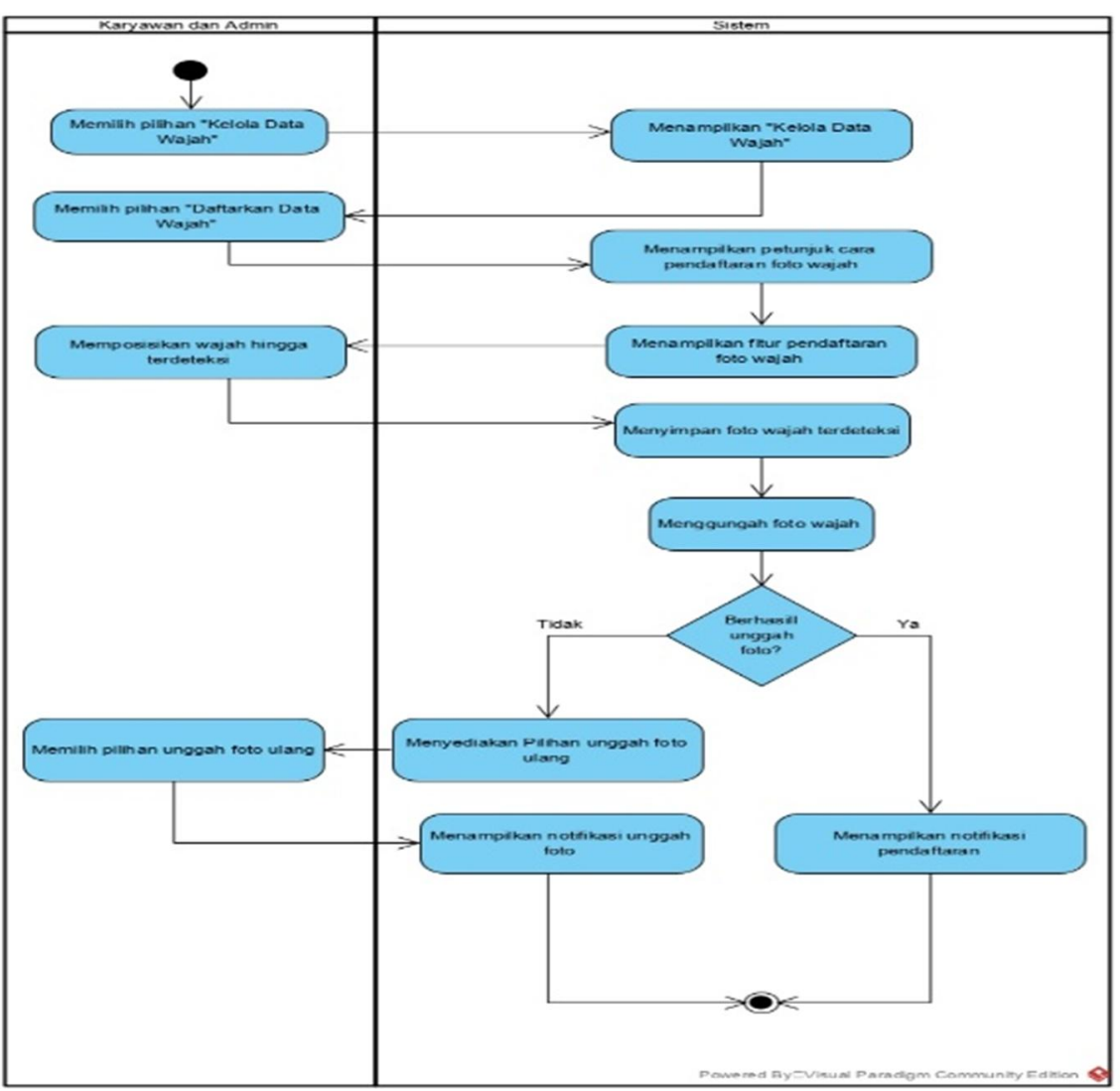

Gambar 3. Activity Diagram Mendaftarkan Wajah

Darmansah, et.,al (Perancangan Absensi Berbasis Face Recognition Pada Desa Sokaraja Lor Menggunakan Platform Android) 


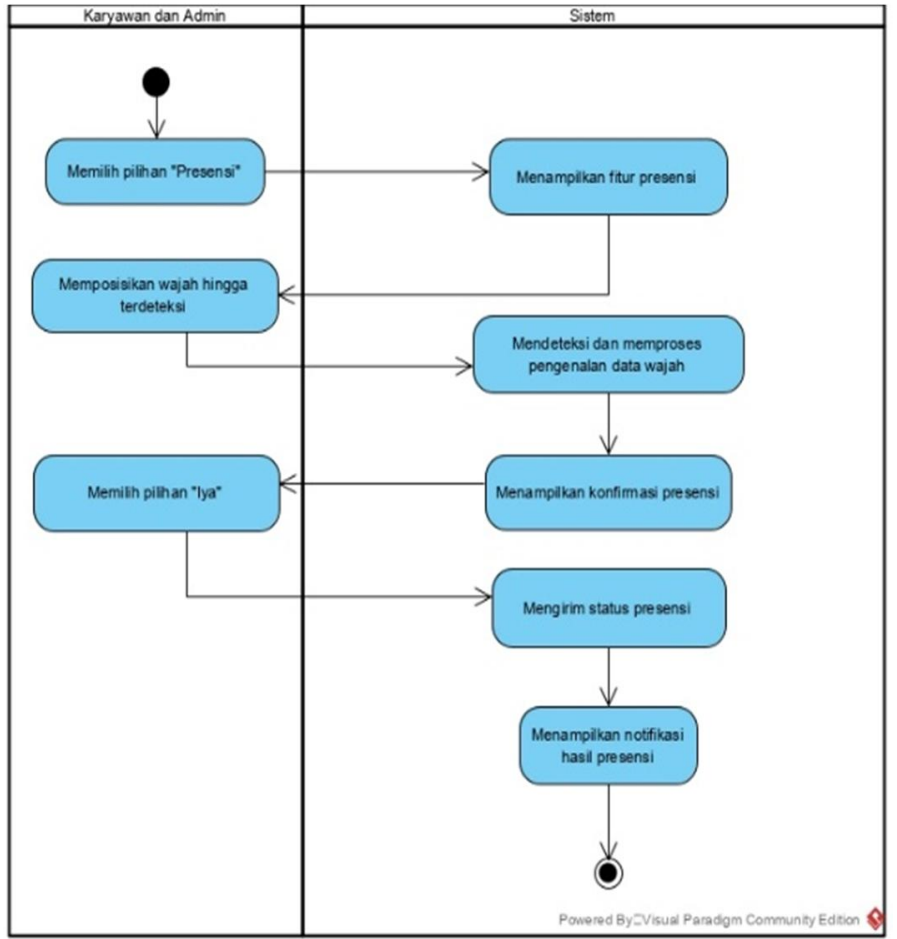

Gambar 4. Activity Diagram Melakukan Presensi

\subsection{Sequence Diagram}

Sequence diagram merupakan sebuah urutan kejadian pada use case login pada sistem. Pada sequence ini terdapat aktor Admin. Dalam sequence login terdapat view login, login Controller entity user. Berikut sequence diagram jika proses login berhasil pada gambar 5 dan 6 dibawah ini:

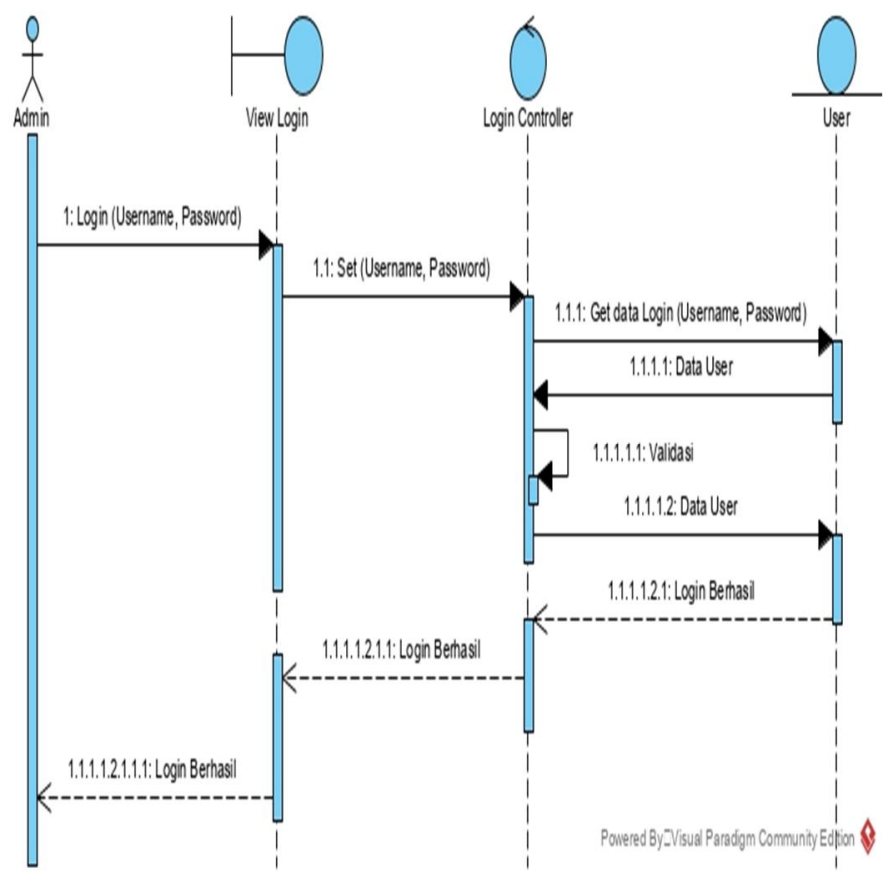

Gambar 5. Sequence Diagram Login Berhasil 
Dan jika admin gagal login kedalam sistem absensi maka rancangan Sequence Diagram nya seperti gamabr 6 berikut ini:

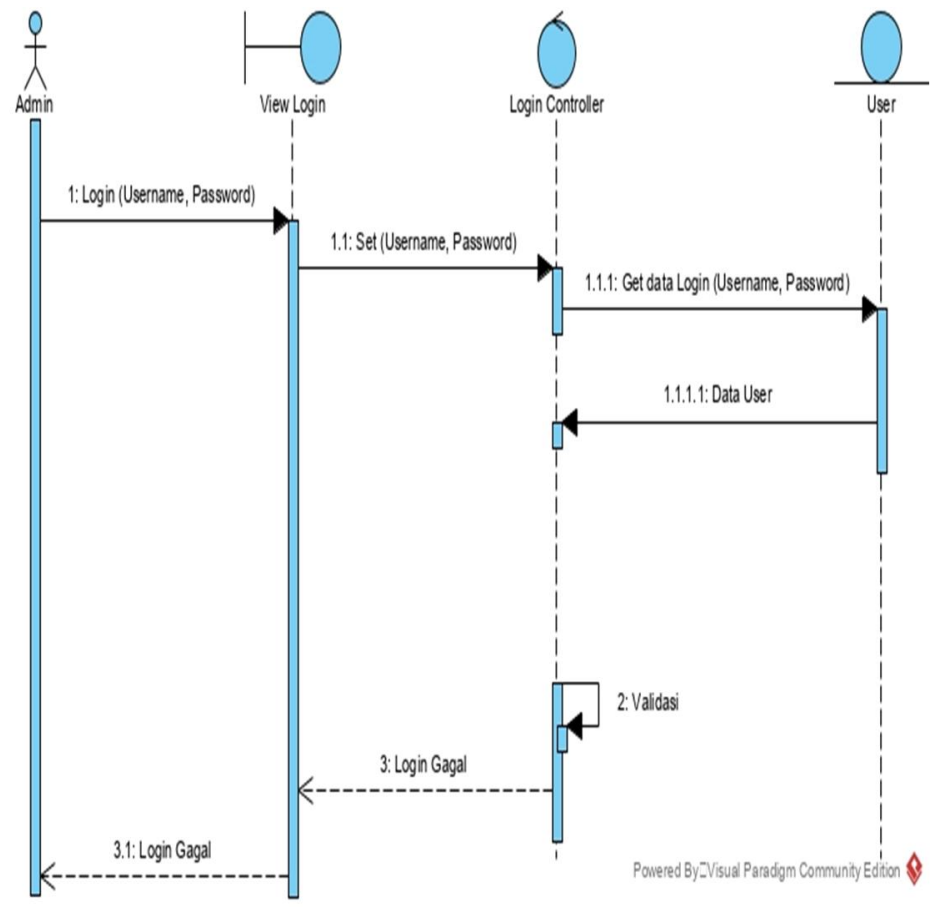

Gambar 6. Sequence Diagram Login Gagal

Kemudian Pada gambar 7 berikut ini adalah sequence diagram mendaftarkan wajah. Pada sequence ini memperlihatkan reaksi sistem ketika pegawai Desa Sokaraja Lor memilih menu mendaftarkan wajah ke sistem yang dimana terdapat menu verifikasi wajah, kelola data set wajah, tambah data set wajah, serta controller verifikasi wajah, kelola data set wajah, daftarkan data wajah dan entity session aplikasi, internal storage.

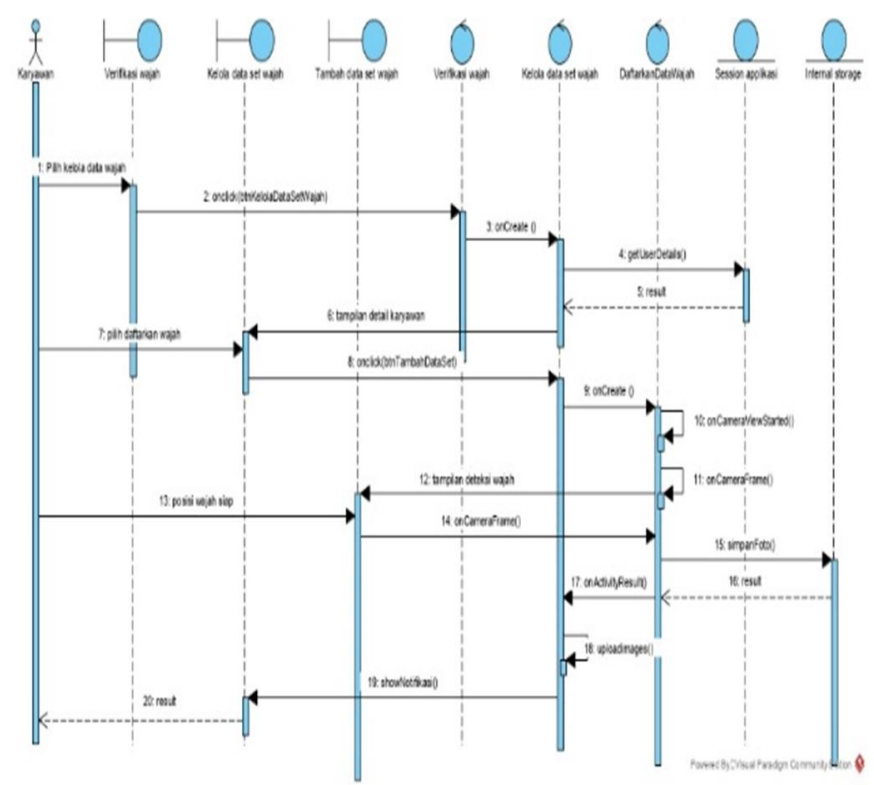

Gambar 7. Sequence Diagram Mendaftarkan Wajah

Darmansah, et.,al (Perancangan Absensi Berbasis Face Recognition Pada Desa Sokaraja Lor Menggunakan Platform Android) 


\subsection{Class Diagram}

Class diagram tersebut menggambarkan kelas-kelas dan objek yang menyusun sebuah sistem absensi berbasis Face Recognition class tersebut dibentuk oleh entity/object yang mempunyai atribut dan operasi. Dari class tersebut dapat terbentuk sebuah tabel yang dapat berasosiasi dengan tabel lainnya, sehingga memungkinkan terbentuknya sebuah database absensi. Adapun bentuk dari clas diagram seperti pada gambar 8 berikut ini:

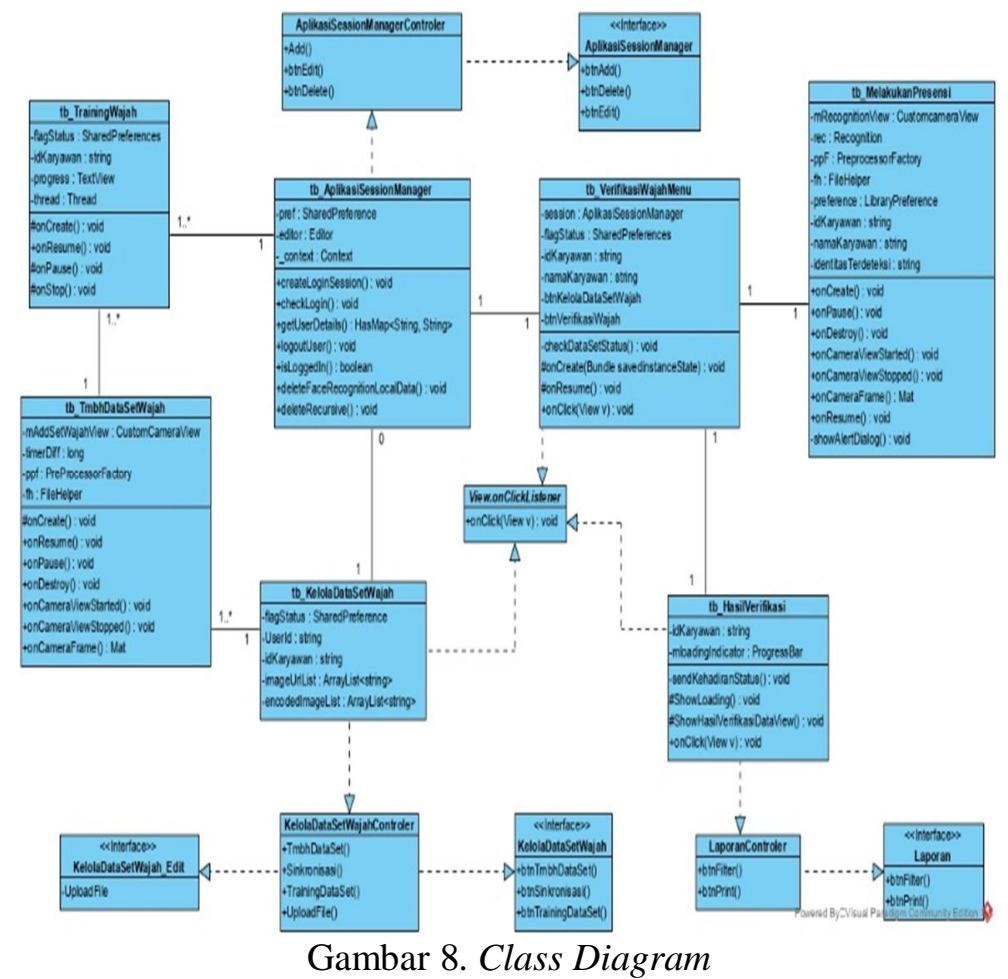

\subsection{Perancangan User Interface}

Sebelum membuat desain absensi Desa Soakaraja Lor dari aplikasi berbasis android dibuat, diperlukan perancangan tampilan dari user yang akan memakai sistem tersebut. Terdapat beberapa rancangan pada sistem ini antara lainnya seperti berikut ini:

\subsubsection{Tampilan Awal Sistem}

Pada gambar 9 merupakan perancangan tampilan pertama sebelum masuk kedalam sistem absensi karyawan atau pegawai desa Sokaraja Lor berbasis facerecognition atau pencocokan wajah ka. Pada tampilan ini terdapat sebuah informasi loading bar yang sedang berjalan untuk masuk kedalam sistem.

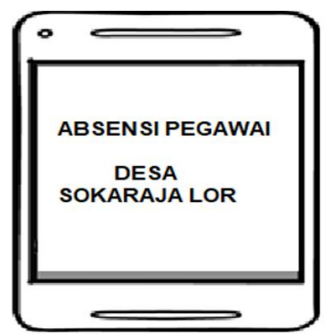

Gambar 9. Tampilan Awal 


\subsubsection{Tampilan Form Login Admin}

Halaman yang ditampilkan pada aplikasi ketika pertama kali dibuka, terdapat 1 user yang dapat melakukan login yaitu admin Desa.Saat admin menekan button login, dan admin sudah memasukan username dan password dengan benar, maka sistem akan menampilkan halaman daftarkan data wajah pegawai desa.

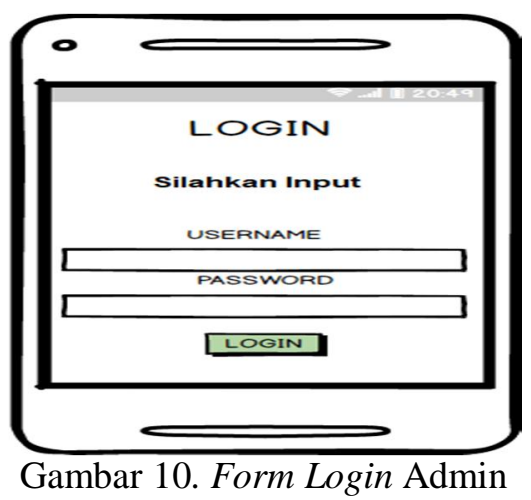

\subsubsection{Tampilan Form Menu Utama Admin}

Form ini merupakan perancangan tampilan menu utama untuk admin. Pada tampilan ini terdapat sebuah informasi desa Sokaraja Lor serta tiga pilihan menu yaitu, pilihan kelola data wajah, pilihan verifikasi kehadiran dan pilihan laporan presensi. Adapun formnya dapat pada gambar 11 berikut ini:

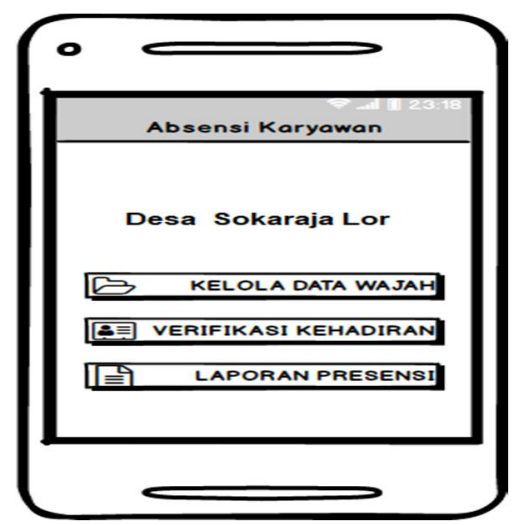

Gambar 11. Tampilan Menu Utama Admin

\subsubsection{Tampilan Form Kelola Data Wajah}

Form merupakan halaman yang ditampilkan pada aplikasi ketika admin memilih pilihan kelola data wajah pada tampilan antarmuka menu utama, halaman ini memuat 3 pilihan fitur kelola data wajah. fitur yang dimiliki antara lain fitur daftarkan data set wajah, fitur latih data set wajah, dan fitur unggah data set wajah. Adapun bentuk formnya seperti gambar 12 berikut ini: 


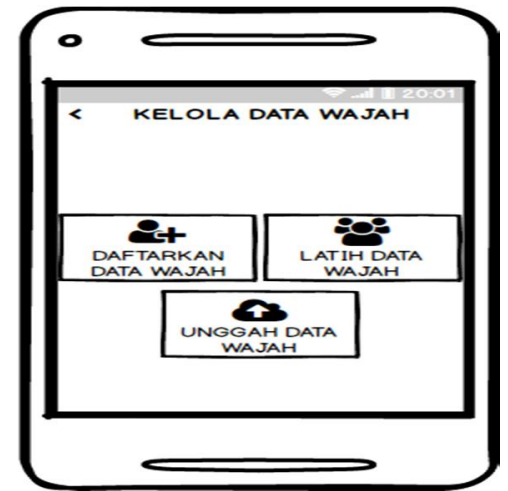

Gambar 12. Tampilan Form Kelola Data Wajah

\subsubsection{Tampilan Form Menu Verifikasi Kehadiran}

Pada form tampilan pada gambar 13 ini merupakan tampilan ketika terdapat wajah yang terdeteksi dan dikenali oleh aplikasi. Pada form ini menampilkan ID pegawai, nama pegawai, divisi bagian pegawai, tanggal melakukan presensi/kehadiran peagawai serta lokasi peagawai tersebut melakukan presensi dimana dan juga ditampilkan progress bar untuk menunjukkan sejauh mana proses pengenalan wajah dilakukan oleh aplikasi. Kemudian pada Gambar 14 merupakan form sebuah dialog untuk konfirmasi pengiriman status kehadiran peagawai.

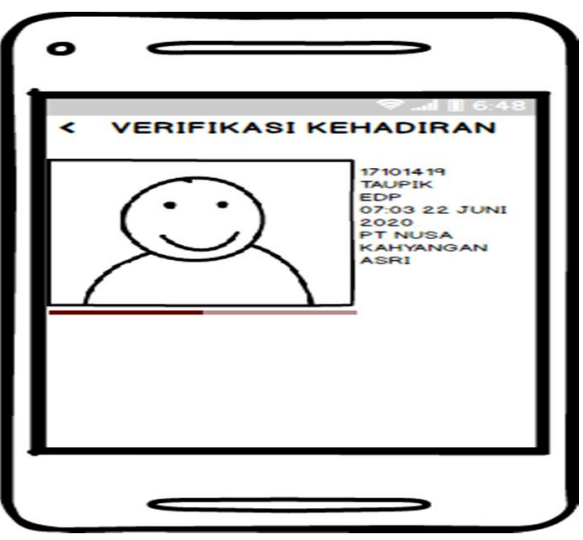

Gambar 13. Output Menu Verifikasi Kehadiran

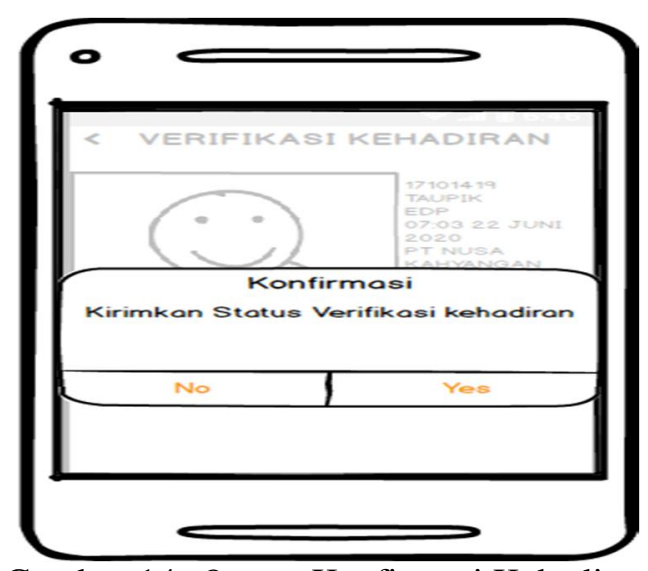

Gambar 14. Output Konfirmasi Kehadiran 


\subsubsection{Tampilan Form Laporan Presensi/ Kehadiran Jam Kerja}

Pada gambar 15 merupakan form tampilan laporan presensi jam kerja pegawai Desa Soakaraja Lor. Pada form ini menampilkan filter tanggal, filterdivisi, filter jam masuk atau pulang dan buttonprint untuk mencetak laporan presensi pegawai.

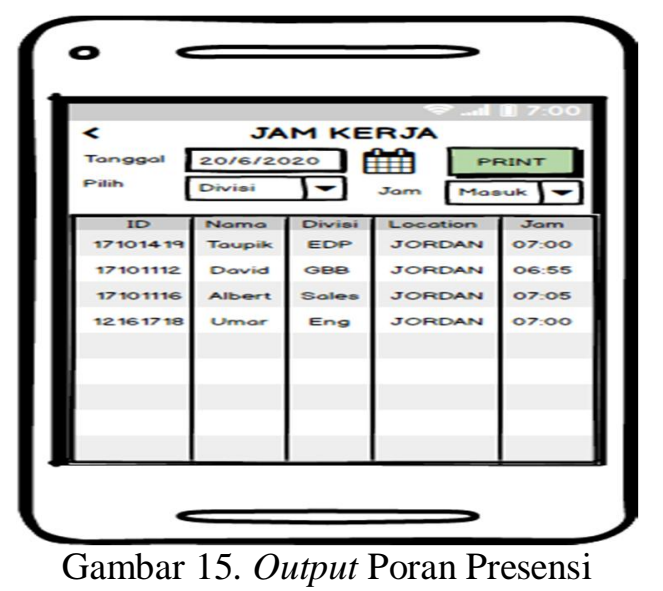

\section{KESIMPULAN}

Berdasarkan hasil pemabahasan dan perancangan absensi berbasis Face Recognition menggunakan platform android dapat disimpulkan bahwa dengan adanya sistem ini pegawai desa lebih mudah untuk melakukan absensi kehadiran. Kemudian bagi staf admin yang mengurusi absensi tersebut lebih gampang mengelola data kehadiran pegawai Desa Soakaraja Lor. Kemudian dengan dibangunnya sistem ini pejabat seperti kepala Desa Sokaraja lor lebih mudah mengelola dan melihat siapa saja pegawainya yang datang tepat waktu dan yang terlambat hali ini tentu akan membuat pegawai desa sokaraja lor lebih tertip dalam melakukan absensi dan pegawai desa juga tidak bisa melakukan titip absen kepada pegawai lainnya karena sudah menggunakan pengenalan wajah dalam proses absensi tersebut.

\section{SARAN}

Adapun saran saran yang peneliti buat pada penelitian ini ialah antara lainnya:

1. Peneliti berharap dilakukan penelitian lebih lanjut terhadap absensi berbasis pengenalan wajah dengan menggunakan android ini pada Desa Sokaraja Lor sehingga sistem ini benar benar mampu di bangun dan memudahkan pegawai dalam melakukan absensi.

2. Untuk penelitian yang serupa dapat meningkatkan fitur-fitur yang ada. Selain itu pembaca bisa menambahkan fitur-fitur lain seperti perhitungan gaji pegawai berdasarkan jumlah hari kerja, perhitungan bonus dan lain sebagainya yang diperlukan oleh sebuah instansi.

\section{DAFTAR PUSTAKA}

[1] Nurhaedar. 2020, Perancangan Sistem Informasi Absensi Kelas Berbasis Qr Code Menggunakan Php \& MySQL pada Kampus Polinas Lp3i Alauddin Makassar, Vol. 2, No. 2, pp. 63-78. 
[2] D. Koswara and E. Cornelius. 2017, Menggunakan Pengenalan Suara (Speech Recognition), Vol. 16, No. 2, pp. 99-106.

[3] Subiantoro and Sardiarinto. 2018, Perancangan Sistem Absensi Pegawai Berbasis Web, J. Swabumi, Vol. 6, No. 2, pp. 184-189.

[4] H. Nugroho and T. Rohimi. 2020, Perancangan Aplikasi Sistem Pengolahan Data Penduduk Dikelurahan Desa Kaduronyok Kecamatan Cisata, Kabupaten Pandeglang Berbasis Web, Vol. 8, No. 1, pp. 1-15.

[5] D. D. Darmansah, 2020, Perancangan Sistem Informasi Pengolahan Jadwal Mata Pelajaran Siswa Secara Online Di Smpn 31 Padang Berbasis Web, JATISI (Jurnal Tek. Inform. dan Sist. Informasi), Vol. 7, No. 3, pp. 451-465, doi: 10.35957/jatisi.v7i3.490.

[6] M. K. Anam, 2018, Metode Eigenface/Principle Component Analysis (PCA) Untuk Identifikasi Wajah Manusia, Vol. 6, No. 2, pp. 82-88.

[7] W. Bayu Syahputra and S. M. Kom, 2019, Sistem Absensi Berbasis Pengenalan Wajah (Face Recognition) Menggunakan Metode Eigenface, pp. 14-16.

[8] A. Muntholib and S. Erlinda. 2019, Prototipe Absensi STMIK AMIK Riau Berbasis Face Recognition Menggunakan Metode Eigenface, SATIN - Sains dan Teknol. Inf., Vol. 4, No. 2, p. 76, doi: 10.33372/stn.v4i2.413.

[9] W. Anggraeni and M. Sri. 2017, Rancang Bangun Aplikasi Pembelajaran Matematika SD Kelas 6 Berbasis Android pada SDN Cimone 1 Tangerang, J. Tek. Univ. Muhammadiyah Tangerang, Vol. 6, No. 2, pp. 1-11, [Online]. Available: https://jurnal.umt.ac.id/index.php/jt/article/download/374/262.

[10] F. S. Susanto, J. Timur, P. Wajah, and P. C. Analysis. 2020, Smartphone Android Dengan Metode Eigenface ( Studi Kasus: STMIK PPKIA Pradnya Paramita Malang), Vol. 4, No. September,

[11] M. Syekh, M. Petungkriyono, and T. Jayengrono, 2020. Sistem Informasi Wisata Religi Islam Kabupaten, No. 1.

[12] D. Yusuf and F. N. Afandi. 2020, Aplikasi Absensi Berbasis Android Menggunakan Validasi Kordinat Lokasi Dan Nomor Handpone Guna Menghindari Penularan Virus Covid 19, Expert J. Manaj. Sist. Inf. dan Teknol., Vol. 10, No. 1, pp. 16-22, doi: 10.36448/jmsit.v10i1.1492.

[13] P. R. Setiawan, Aplikasi Absensi Online Berbasis Android, IT J. Res. Dev., Vol. 5, No. 1, pp. 63-71, 2020, doi: 10.25299/itjrd.2020.vol5(1).5120.

[14] A. R. I. Jeannefer Monica Santoso. 2020, Rancang Bangun Aplikasi Jurnal dan Absensi pada Studi Center di Wilayah Cengkareng Barat Berbasis Android.

[15] U. Rahmalisa, Y. Irawan, and R. Wahyuni. 2020, Aplikasi Absensi Guru Pada Sekolah Berbasis Android Dengan Keamanan Qr Code (Studi Kasus: SMP Negeri 4 Batang Gansal), Riau J. Comput. Sci., Vol. 6, No. https://e- 
journal.upp.ac.id/index.php/RJOCS/issue/view/152, pp. 135-140, [Online]. Available: https://e-journal.upp.ac.id/index.php/RJOCS/article/download/2059/1587. 